\title{
Função social do contrato. Conceito. Natureza jurídica e fundamentos.
}

\author{
Social function of contract. Concept. Legal nature and juridical basis.
}

Jussara Schmitt Sandri ${ }^{1}$

\section{Resumo}

\begin{abstract}
A transformação da teoria geral dos contratos resultou no surgimento de novos preceitos, visando equilíbrio e harmonia na relação contratual, por meio da observância de princípios como a boa-fé objetiva e a função social dos contratos, norteados na dignidade da pessoa humana e no intervencionismo estatal. 0 presente estudo analisa a função social dos contratos, com enfoque nos direitos da personalidade, abordando natureza jurídica e fundamentos, suas principais características e a eventual restrição ao princípio da liberdade contratual.
\end{abstract}

Palavras Chave: Contratos; Função social; Direitos da personalidade; Liberdade contratual.

\section{Abstract}

The transformation of the theory of contracts resulted in the publication of new principles, to balance and harmony in the relationship, through the observance of principles such as objective good faith and the social function of contracts, guided in human dignity and state interventionism. This study examines the social function of contracts, intented on personality's rights, addressing juridical nature and basis, its main characteristics and supposed restriction on the principle of freedom contract.

Keywords: Contract; Social function; Personality's rights; Freedom of contract.

\section{Introdução}

0 presente estudo tem o propósito de analisar a função social dos contratos, discutindo conceito, natureza jurídica e fundamentos. Os direitos da personalidade

\footnotetext{
${ }^{1}$ Mestranda em Ciências Jurídicas pelo Centro Universitário de Maringá. Servidora pública federal Docente e coordenadora de estágio do Colegiado de Direito do Instituto Federal do Paraná. E-mail: ss.jussara@gmail.com
} 
envolvem a pesquisa, na medida em que vinculam-se ao princípio da dignidade da pessoa humana.

A função social dos contratos, como princípio adotado pela nova teoria geral contratualista, ao lado dos princípios da boa-fé objetiva e do equilíbrio contratual, surge para possibilitar a isonomia entre as partes contratantes, visando maior harmonia na relação contratual.

Será analisado o conceito de função social dos contratos, pretendendo-se discutir as principais características e controvérsias que envolvem sua delimitação.

0 estudo da natureza jurídica desse preceito se mostra relevante, e a análise dos fundamentos que o norteiam, uma vez que, embora tenha sido previsto na legislação pátria expressamente em 2002, já se fazia presente no sistema jurídico nacional, não só admitido pela doutrina, mas amplamente discutido nos tribunais.

Apresentar-se-ão alguns debates, sendo abordadas as altercações mais significativas, notadamente ao cotejar a função social dos contratos com a liberdade contratual, demonstrando eventuais restrições ou convergências entre tais preceitos, além do estudo de outras questões relevantes para melhor compreensão do tema.

\section{Conceito de função social dos contratos}

Conceituar a função social dos contratos é tarefa que demanda análise cuidadosa, porque tratar-se-ia de conceito indeterminado, conforme Pablo Stolze Gagliano e Rodolfo Pamplona Filho, ao demonstrar a importância dos princípios da função social do contrato, da equivalência material e da boa-fé objetiva:

[...] a grande contribuição da doutrina civil moderna foi trazer para a teoria clássica do direito contratual determinados princípios e conceitos, que, posto não possam ser considerados novos, estavam esquecidos pelos civilistas. Como se pode notar, tratam-se de cláusulas gerais ou conceitos abertos (indeterminados) que, à luz do princípio da concretude, devem ser preenchidos pelo juiz, no caso concreto, visando a tornar a relação negocial economicamente útil e socialmente valiosa. (GAGLIANO, 2005, p.49).

Com a evolução histórica e as mudanças ocorridas no contexto social, o Estado passou a adotar uma postura intervencionista nas relações privadas. Nesse sentido, M ariza Rotta e Cleide Aparecida Gomes Rodrigues Fermentão esclarecem: 
Haverá um intervencionismo, cada vez maior, do Estado nas relações contratuais, que deixa conceitos como o individualismo e o voluntarismo, símbolo do liberalismo decadente, do século XIX de lado, e passa a ter preocupações de ordem social, com a imposição de um novo paradigma, o princípio da boa-fé objetiva e a busca do Estado Social. (ROTTA, 2008, p.194-218).

Não se pode olvidar, porém, que os contratos tiveram seu reconhecimento formal com a Revolução Francesa. Na transição entre absolutismo e liberalismo, surge o liberalismo econômico, o individualismo e o voluntarismo.

Da conjunção dos fatores fortalecimento econômico da burguesia e construção teórica das origens e função do Estado por meio dos lluministas, o movimento, que culminou com a Revolução Francesa e a derrubada do modelo absolutista então vigente, pretendia antes de tudo a igualdade entre os homens e a sujeição do Estado a um ordenamento jurídico que lhe conferisse limites. (SETTI, 2010, p.415).

A teoria clássica dos contratos prevê a igualdade formal entre as partes e a liberdade de contratar, como consequência dos ideais de igualdade e de fraternidade da Revolução Francesa. Mas esta teoria não se mostrava satisfatória e, com o decorrer do tempo, o Estado passou a atuar de forma intervencionista nas relações negociais, sendo que, no Brasil, o intervencionismo estatal é enfatizado na Constituição Federal, promulgada em 1988.

Com essa intervenção pública nas relações negociais, o contrato, que visa criar, regular, modificar ou extinguir relações jurídicas, possui como elementos as partes, o objeto e o consenso entre contratantes, ou seja, entre as pessoas.

No escólio de Humberto Theodoro Júnior, os contratos estão revestidos, hodiernamente, de preceitos de ordem pública, da função social do contrato, da supremacia do interesse público em detrimento do particular e da boa-fé objetiva:

É inegável, nos tempos atuais, que os contratos, de acordo com a visão social do Estado Democrático de direito, hão de submeter-se ao intervencionismo estatal manejado com 0 propósito de superar 0 individualismo egoístico e buscar a implantação de uma sociedade presidida pelo bem-estar e sob efetiva prevalência da garantia jurídica dos direitos humanos. (THEODORO JUNIOR, 2004, p.6).

Carlos Roberto Gonçalves, defendendo o caráter restritivo da função social do contrato, leciona que este "constitui, assim, princípio moderno a ser observado pelo intérprete na 
aplicação dos contratos. Alia-se aos princípios tradicionais, como o da autonomia da vontade e da obrigatoriedade, muitas vezes impedindo que estes prevaleçam." (GONÇALVES, 2010, p.25).

É necessário, pois, vislumbrar a relação do contrato com o seu contexto social e não apenas sob o prisma individual, relativo aos contratantes, porque o contrato passou a interferir negativa e positivamente, também, em relação à coletividade. Nelson Nery Junior (2003, p.336) indica que a função social traz consigo valores de ordem jurídica, social, econômica e moral.

Nesse ponto, a função social do contrato presente no ordenamento jurídico, no âmbito das relações privadas e sociais, deve ser analisada de acordo com sua aplicabilidade na esfera jurídica, na medida em que o contrato passa a ter uma aplicação voltada ao social, viabilizando a igualdade das partes e o equilíbrio contratual.

No escorço de Gagliano e Pamplona filho, "a relação deverá compreender os deveres jurídicos gerais e de cunho patrimonial (de dar, fazer, ou não fazer), bem como deverão ser levados em conta os deveres anexos ou colaterais que derivam desse esforço socializante". (GAGLIANO, 2005, p.53).

Os autores prosseguem, afirmando que:

A função social do contrato é, antes de tudo, um princípio jurídico de conteúdo indeterminado, que se compreende na medida em que lhe reconhecemos o precípuo efeito de impor limites à liberdade de contratar, em prol do bem comum. (GAGLIANO, 2005, p.55).

Desta forma, a função social do contrato integra o instituto da função social, a qual também abrange a função social da propriedade.

Confluindo para tal entendimento da função social do contrato alicerçada na função social da propriedade, a doutrina de Gagliano e Pamplona Filho assim dispõe: "o contrato é figura que acompanha as mudanças de matizes da propriedade, experimentando inegável interferência deste direito" (GAGLANO, 2005, p.47). Aliás, nesse sentido, Maria Estela Leite Gomes Setti enfatiza:

[...] a Constituição Cidadã trouxe em seu texto os delineamentos deste novo direito, ao determinar, logo em seu artigo inaugural que um dos fundamentos do Estado Democrático de Direito em que se constitui a República brasileira é a dignidade da pessoa humana. Mais adiante, em seu artigo 3o, estabelece como objetivo da República, entre outros, a construção de uma sociedade livre, justa e 
solidária. No artigo 170, ao enumerar os princípios da ordem econômica, 0 legislador constituinte deixou claro que a ordem econômica é fundada na valorização do trabalho humano e na livre iniciativa e tem por fim garantir a todos existência digna conforme os ditames da justiça social. (SETTI, 2010, p.419).

Deste modo, a socialização da noção de propriedade, analisada em consonância com o seu papel social, foi erigida na Constituição Federal como um direito fundamental, apresentando, em relação aos contratos, uma nova abordagem, tanto em sua elaboração, quanto em suas conseqüências fáticas para os contratantes e, principalmente, em sua repercussão na coletividade, notadamente porque,

Todo o Direito é relativo e dinâmico, e por isto, sempre questionável ou polêmico. Mas o Direito das Obrigações, e particularmente, o Direito dos Contratos, tem estas características ainda mais acentuadas, seja porque trata das causas e dos efeitos das relações jurídicas entre as pessoas, que estão em toda parte, e as pessoas, claro, são imprevisíveis; porque abrange toda a manifestação de vontades, simplesmente a força vital da humanidade, e esta é insaciável; ou ainda, porque lida com a constituição, a extinção e a modificação de direitos, sem os quais, não é possível criar, mudar ou findar direitos sem esbarrar no emaranhado de interesses e garantias de um sistema que o próprio ser humano estabeleceu. Conhecer os contratos é, assim, fundamental. (ROTTA, 2008, p.195).

No que se refere à atuação das partes na relação contratual, essa nova abordagem alterou até mesmo as consequências das relações, na medida em que visa um contrato com atuação isonômica e indene de cláusulas abusivas, que possam onerar excessivamente um dos contratantes ou até mesmo lhe causar prejuízos, promovendo a igualdade entre as partes e a liberdade dos indivíduos.

Ponderando que, sob o ponto de vista econômico, igualdade e liberdade não se equivalem, Antônio Jeová Santos esclarece que a "sanção de normas de ordem pública serviu para amparar o economicamente mais fraco, diante do poderio da parte contratante. Ao mais fraco deveria ser conferido um mínimo de bem-estar social e econômico". 0 autor adverte, ainda, que, "Tratando bem o indivíduo, sai ganhando to da a sociedade". (SANTOS, 2004, p.195)

Nesse diapasão, não se pode olvidar do princípio da dignidade da pessoa(ROSENVALD, 2007, p. 201), como parte da própria essência do ser humano, que antecede e fundamenta a ordem política ao inserir a pessoa como protagonista do sistema jurídico de forma negativa, com o intuito de evitar qualquer atentado à estima e ao respeito 
à sua dignidade, e, de forma positiva, ao possibilitar que o ordenamento jurídico propicie um ambiente de liberdades por meio de um mínimo invulnerável, visando o desenvolvimento de suas aptidões e o exercício de seus interesses, tendo garantidas condições verdadeiramente humanas.

A expressão "dignidade da pessoa humana" não é supérflua, tampouco redundante. Demonstra que a dignidade não pode ser aferida por padrões individuais, pois não basta que o indivíduo seja livre, mas que pertença, por essência, à humanidade. Uma humanidade na qual os indivíduos jamais deixam de ser um fim, sob pena de conversão em meios para os fins alheios. Essa visão auxilia 0 intérprete em uma percepção menos abstrata e mais efetiva do princípio, uma vez que, enquanto $o$ valor liberdade se conecta imediatamente com as nossas expectativas individuais, a dignidade nos remete a tudo aquilo que concerne ao gênero humano. (ROSENVALD, 2007, p.201)

Diante disto, os princípios da liberdade de contratar, da força obrigatória dos contratos e da relatividade dos seus efeitos não são mais os únicos a nortear 0 direito contratual. M elissa Cunha Pimenta esclarece:

\begin{abstract}
A adoção de novos paradigmas no direito privado resulta em uma releitura dos princípios contratuais clássicos, oriundos da visão liberal do direito, passando estes a coexistir com os novos princípios contratuais, sendo: o princípio da boa-fé objetiva; princípio do equilíbrio contratual e princípio da função social do contrato. [...] nenhum dos princípios clássicos foi abolido, o que houve foi uma relativização destes, com a aplicação de novos princípios, ditos "sociais" e "éticos", oriundos de uma nova concepção do direito. (PIM ENTA)
\end{abstract}

Ana Laura Teixeira M artelli, ao tratar do princípio da boa-fé objetiva, aduz que este "deve nortear todo o ordenamento jurídico e condicionar o comportamento das pessoas em suas relações jurídicas de forma honesta, proba e leal, prestigiando a confiança nas relações sociais." (M ARTELLI, 2011, p. 29)

O princípio da função social do contrato, previsto no art. 421 do Código Civil, é assim delineado: "A liberdade de contratar será exercida em razão e nos limites da função social do contrato". A propósito, segundo a lição de Carlos Roberto Gonçalves, a "função social do contrato constitui, assim, princípio moderno a ser observado pelo intérprete na aplicação dos contratos." (GONÇALVES, 2010, p.25). 
Na nova concepção de contrato, frente ao $\mathrm{CDC}$ e ao novo $\mathrm{CC}$, não mais importa somente a manifestação de vontade dos contraentes, devendo-se levar em conta, também, os efeitos deste na sociedade, bem como a condição econômica e social dos participantes da relação jurídica. Na busca deste novo equilíbrio, o direito terá um papel destacado na busca da delimitação imposta pela lei, que também será legitimadora da autonomia de vontade das partes, passando a proteger determinados interesses, agora não de cunho individual, mas de interesse social, valorizando a confiança do vínculo de contratação, as expectativas e a boa fé. (ROTTA, 2008, p.207).

Denota-se, deste modo, que o conceito de função social é amplo e indefinido, inobstante o teor do art. 421 do Código Civil, o que privilegia a exegese do magistrado, ao conceder tutela jurisdicional eventualmente invocada por uma das partes contratantes, motivo pelo qual, tal conceito deve ser preenchido "pelo juiz, no caso concreto, visando a tornar a relação negocial economicamente útil e socialmente valiosa". (GAGLIANO, 2005, p.49)

Nesse diapasão, importa frisar a lição de Gadamer, que enfatiza o papel do magistrado na aplicação do Direito, ao afirmar que o "juiz é, antes de mais nada, um intérprete, pois, para aplicar o Direito, deve, em primeiro lugar, compreender a norma". (GADAM ER, 1997, p.483).

Interpretar é aplicar, e para tanto o juiz tem um papel fundamental de manter a ordem judicial seguindo as determinações legais e ao mesmo tempo usando da ponderação para que se realize a verdadeira justiça. Nessa interação feita pelo juiz diante do caso concreto é que consiste a pura hermenêutica. (LOUREIRO, 2008, p.5683-5684).

Desta forma, é necessário ter a compreensão e a interpretação do texto original relativo à função social do contrato, para só então aplicar-se a norma ao caso concreto. "A compreensão, a interpretação e a aplicação, que eram três momentos diferentes segundo a antiga hermenêutica, sob a teoria de Gadamer adquiriram caráter indivisível". (LOPES, 2000)

Compreensão, interpretação e aplicação não são três momentos independentes, mas formam um processo unitário, pois a aplicação da norma é tão essencial e integral como a sua compreensão e interpretação.

Na medida em que o conceito de função social do contrato é amplo e indefinido, deve 0 magistrado ter a compreensão e a interpretação do que preceitua 0 art. 421 do Código Civil, e, mediante uma análise sistemática, só então aplicar a norma ao caso 
concreto, tendo a prerrogativa de realizar a exegese na hipótese de demanda fundada em violação da função social do contrato.

Função social dos contratos no contexto dos direitos da personalidade

Os direitos da personalidade reconhecem os valores inerentes à pessoa humana, imprescindíveis ao desenvolvimento de suas potencialidades físicas, psíquicas e morais, tais como a vida, a saúde física e psíquica, dentre outros.

De acordo com Carlos Alberto Bittar, os direitos da personalidade são aqueles "reconhecidos à pessoa humana tomada em si mesma e em suas projeções na sociedade, previstos no ordenamento jurídico exatamente para a defesa de valores inatos no homem, como a vida, a higidez física, a intimidade, a honra, a intelectualidade e outros tantos" (BITTAR, 2004, p.1), vinculados de forma indissociável ao reconhecimento do princípio da dignidade da pessoa humana, como qualidade necessária ao incremento das potencialidades físicas, psíquicas e morais de todo ser humano.

A personalidade "refere-se ao que de mais íntimo o indivíduo possa ter, e isto é vulnerável durante toda a existência" (MOTTA, 2009, p. 627-628), sendo certo que "os direitos da personalidade são limites impostos contra o poder público e contra os particulares na proteção da pessoa humana, garantindo o seu desenvolvimento e sua própria existência" (SPINELI, 2008, p. 373).

No âmbito do Código Civil, é possível observar que

A tutela da pessoa natural é construída com base em três preceitos fundamentais constantes no Texto M aior: a proteção da dignidade da pessoa humana (art. 1인 III); a solidariedade social, inclusive visando a erradicação da pobreza (art. 3ㅇ, I e II); e a igualdade em sentido amplo ou isonomia. (TARTUCE)

A propósito disto, Nelson Rosenvald trata do conceito de pessoa, relacionando-a ao princípio da dignidade humana, ao lecionar que:

A reconstrução do conceito de pessoa, com a exaltação do ser por suas qualidades intrínsecas e não pela sua conjuntura econômica, deve ser creditada ao princípio da dignidade da pessoa humana, como valor fundante de toda a ordem privada. (ROSENVALD, 2007, p.21-22). 
Rabindranath, ao tratar dos direitos da personalidade e dos direitos do homem, esclarece que "há direitos do homem, particularmente os subdenominados "civis", que tutelam bens humanos também protegidos pelos direitos de personalidade (v.g., a vida, a integridade física, a liberdade, a segurança, a intimidade da vida privada)". (CAPELO DE SOUZA, 1995, p.550-591).

De acordo com o entendimento de Nelson Rosenvald,

A dignidade da pessoa humana é o núcleo essencial dos direitos da personalidade. No constitucionalismo moderno, a tutela ao ser humano é positivada mediante direitos fundamentais, cuja fonte é a dignidade da pessoa humana. A dignidade da pessoa humana como elemento fecundante inspira proteção integral, esmaecendo as fronteiras entre as situações jurídicas inicialmente vinculadas ora aos direitos humanos, ora aos direitos de personalidade. (ROSENVALD, 2007, p.202).

Há direitos da personalidade, porém, que não estão expressamente previstos na legislação pátria, uma vez que esta prevê esses direitos como cláusulas numerus abertus. Entretanto, não é sensato estimular a tendência expansionista, pretendendo que qualquer situação possa ser tipificada como um direito da personalidade. Exemplifica-se, invocando o direito à propriedade, que não é um direito da personalidade, uma vez que existe um microsistema próprio que regulamenta e protege os fundamentos da propriedade. Ainda que 0 direito à propriedade possibilite o desenvolvimento da pessoa, respeitada a dignidade humana, denota-se que o direito à propriedade viabiliza e contribui para o desenvolvimento dos direitos da personalidade.

Apesar do traço em comum com a propriedade [a dignidade da pessoa humana], desta se distancia pelo caráter extrapatrimonialista, pois, relembrando a célebre noção kantiana, a dignidade reside unicamente nos bens inestimáveis. (ROSENVALD, 2007, p.23).

Desta forma, sob o aspecto funcional, denota-se que a função contratual colabora para o desenvolvimento dos direitos da personalidade, porém, não pode ser elencada como tal, porque, se a função social do contrato for aviltada, por exemplo, por eventual mudança no regime econômico, haverá um desrespeito aos direitos da personalidade, na medida serão tolhidos aqueles costumes a que a pessoa estava habituada.

O contrato, pois, é o caminho (ou um dos caminhos) para a obtenção de bens jurídicos que dão sustentáculo à vida, como segurança e saúde, consubstanciado num 
instrumento que auxilia na concretude dos direitos da personalidade, uma vez respeitada a sua função social.

\section{Natureza jurídica da função social dos contratos}

A natureza jurídica da função social do contrato, para ser compreendida, deve ser analisada sob a premissa de que o contrato "não pode trazer onerosidade excessiva, desproporção e injustiça social, bem como, não pode violar interesses individuais que abranjam a proteção da dignidade humana." (BASSO, 2008, p.46)

O princípio da função social dos contratos, conforme mencionado alhures, importa na necessidade de vislumbrar a relação do contrato com o seu contexto social e não apenas sob o prisma individual, relativo aos contratantes, porque 0 contrato apresenta consequências, também, em relação à sociedade.

Nelson Nery Junior aporta que a função social dos contratos possui a condição de cláusula geral, de modo que:

0 contrato estará conformado à sua função social quando as partes se pautarem pelos valores da solidariedade (CF, art. 3o, I) e da justiça social (CF, art. 170 caput), da livre-iniciativa, for respeitada a dignidade da pessoa humana (CF, art. 1으, III), não se ferirem valores ambientais (CDC, 51, XIV) etc. (NERY JUNIOR, 2003, p.336)

Por outro lado, o princípio da função social será violado, dentre outras, nas hipóteses em que seus efeitos venham a prejudicar os interesses da sociedade, ou mesmo de terceiros que não tenham relação direta ao negócio jurídico pactuado. A propósito disto, Nelson Nery Junior indica algumas situações de inobservância da função social do contrato, afirmando que

Haverá desatendimento da função social, quando: a) a prestação de uma das partes for exagerada ou desproporcional, extrapolando a álea normal do contrato; b) quando houver vantagem exagerada para uma das partes; c) quando quebrar-se a base objetiva ou subjetiva do contrato, etc. (NERY JUNIOR, 2003, p. 336)

Flávio Tartuce, por sua vez, esclarece que a função social do contrato é uma norma geral "de ordem pública, conforme previsão do art. 2.035, parágrafo único, do próprio Código Civil", pela qual o contrato deve ser necessariamente visualizado e interpretado de acordo com o contexto da sociedade, aportando que "não pode o contrato trazer 
onerosidades excessivas, desproporções, injustiça social." Para o autor, os contratos não podem, também, "violar interesses metaindividuais ou interesses individuais relacionados com a proteção da dignidade humana". (TARTUCE, 2006)

0 que se verifica com relação à natureza jurídica da função social do contrato, diz respeito ao princípio da sociabilidade que foi adotado pelo novo Código Civil, o qual encontra-se em consonância com a Constituição Federal, demonstrando que 0 contrato tem prevalência dos valores coletivos sobre os individuais, porém, sem deixar de considerar o valor fundamental da pessoa humana. Assim, pode-se dizer que, a função social do contrato é o reconhecimento, ainda que tardio, da função precípua, inerente, e essencial do contrato, isto porque, o contrato surge como forma de conceder ao homem o suprimento de suas deficiências naturais e individuais, como veículo orientador da vida humana e social. (BASSO, 2008, p. 47)

Pablo Stolze Gagliano, ao analisar o parágrafo único do art. 2035 do Código Civil, ressalta a intenção do legislador, de caracterizar a função social do contrato como um preceito de ordem pública.

Utilizando a expressão "nenhuma convenção", o legislador impõe a todos os negócios jurídicos, não importando se celebrados antes ou após a entrada em vigor do novo Código, a fiel observância dos seus preceitos de ordem pública, especialmente a função social da propriedade e dos contratos. (GAGLIANO 2003)

A função social do contrato, no escorço de Paulo Nalin, divide-se em intrínseca relativa à observância dos princípios da igualdade material, equidade e boa-fé objetiva pelos contratantes, decorrentes da cláusula constitucional da solidariedade; e extrínseca destinada a observar as consequências do contrato nas relações sociais, considerando os seus reflexos a outros titulares que não somente os contratantes. (NALIN, 2001, p.226)

0 princípio da função social do contrato é uma norma geral de ordem pública, prevista expressamente no ordenamento jurídico pátrio, sendo certo que, por meio dessa norma geral pública, o contrato deve ser necessariamente visualizado e interpretado de acordo com o contexto da sociedade.

A propósito, Pablo Stolze Gagliano analisa as normas gerais de ordem pública: “determinadas normas, como a que prevê a resolução por onerosidade excessiva ou a correção econômica das prestações pactuadas, em nosso pensamento, por seu indiscutível caráter publicístico e social, não podem, aprioristicamente, ser afastadas pela vontade das partes". (GAGLIANO, 2003) 
Assim, a função social dos contratos, reconhecida como norma geral de ordem pública, não admite convenção particular contrária à função social, de modo que, eventual cláusula nesse sentido, deve ser afastada pelo magistrado.

\section{A função social do contrato e o princípio da liberdade contratual}

A redação do art. 421 do Código Civil, que trata do princípio da função social dos contratos, enseja algumas ponderações:

[...] este artigo apresenta alguns pontos polêmicos. 0 primeiro deles é de que não se trata de liberdade de contratar, e sim de liberdade contratual, já que é esta que está relacionada com o conteúdo do contrato. 0 outro erro é que a função social não é razão do contrato, a função social é limite do contrato. (M ELLO)

Nesse contexto, o clássico princípio da autonomia da vontade sofreu sérias restrições, dado o surgimento da nova principiologia contratual e do intervencionismo estatal.

Para César Fiúza, a autonomia da vontade pode ser exercida em quatro planos, quais sejam: a liberdade de "contratar ou não contratar; determinar com quem e o que contratar; estabelecer as cláusulas contratuais, respeitados os limites da Lei, e; mobilizar ou não o judiciário para fazer respeitar o contrato." (FIUZA)

Arnoldo Wald, por sua vez, apregoa que o princípio da autonomia da vontade se apresenta sob duas formas distintas, ou seja, a liberdade de contratar e a liberdade contratual, distinguindo os do is institutos:

'Liberdade de contratar' é a faculdade de realizar ou não determinado contrato, enquanto a 'liberdade contratual' é a possibilidade de estabelecer o conteúdo do contrato. A primeira se refere à possibilidade de realizar ou não um negócio, enquanto a segunda importa na fixação das modalidades de sua realização. (WALD, 1992, p. 153)

Ainda que 0 art. 421 do Código Civil preconize a limitação da liberdade de contratar, refere-se, em verdade, à liberdade contratual, porque a oportunidade e a conveniência de contratar não sofre entraves, porque as partes possuem a prerrogativa de optar pela realização ou não do contrato. 0 que efetivamente sofre significativas limitações é a chamada liberdade contratual. Esta sim, 
Sofre restrições em virtude da ordem pública, que representa a projeção do interesse social nas relações interindividuais. 0 'ius cogens', 0 direito imperativo defende os bons costumes e a estrutura social, econômica e política da comunidade". (WALD, 1992, p. 154)

Outra incongruência observada no texto do art. 421 do Código Civil refere-se ao papel da função social como razão do contrato. Ocorre, porém, que a função social configura-se no limite do contrato, da liberdade contratual. Em outras palavras e de acordo com Antônio Junqueira de Azevedo (1998, p. 115), o contrato deve ser realizado nos limites e em consonância com sua função social.

0 objeto da autonomia privada desenvolve-se no plano social e a negação da autonomia viola os princípios do direito natural, servindo como proteção constitucional da atividade econômica e para promover o desenvolvimento social. Até porque, a autonomia privada é criadora de relações jurídicas, pelo exercício da própria vontade, ou seja, seria a regulação dos interesses da pessoa. Somente terá eficácia, a autonomia privada, se gerar efeitos jurídicos.

O negócio jurídico, como expressão da autonomia privada, difere da autonomia da vontade. Ora, se direito é a conjunção de dois pólos que se integram e se limitam, a liberdade não se confunde com a liberdade natural, que é aquela liberdade pré-jurídica, abstraindo-se a idéia de Estado, de sociedade organizada, que foi mudando ao longo do tempo, disciplinando o sistema natural para regular as relações jurídicas.

A liberdade concedida pelo ordenamento deixa de ser uma liberdade natural, pois demanda autorização, ou seja, os efeitos são provocados pelo impulso do sujeito, porém, desde que permitido e até mesmo protegido pelo ordenamento jurídico.

Portanto, a função social do contrato possui o papel de limitar a autonomia contratual, com o objetivo precípuo de evitar que a liberdade contratual seja exercida abusivamente, garantindo, pois, o equilíbrio entre as partes e que o negócio jurídico atenda aos interesses sociais, sem prejuízos à coletividade.

\section{Fundamentos da função social dos contratos}

Para a análise dos fundamentos da função social dos contratos, importa relembrar que o contrato, na moderna definição de Gagliano e Pamplona Filho, trata-se de um 
"negócio jurídico por meio do qual as partes declarantes, limitadas pelos princípios da função social e da boa-fé objetiva, autodisciplinam os efeitos patrimoniais que pretendem atingir, segundo a autonomia das suas próprias vontades". (GAGLIANO, 2006, p. 11)

Pontes de Miranda leciona que "o negócio jurídico bilateral, notadamente 0 contrato, resulta da entrada no mundo jurídico de vontade acorde dos figurantes, com irradiação dos efeitos próprios". (PONTES DE MIRANDO, 1959, p. 7)

0 princípio da função social do contrato tem seu fundamento constitucional no princípio da solidariedade e na afirmação do valor social da livre iniciativa, cabendo ao Código Civil, enquanto legislação infraconstitucional, consolidar a funcionalização do contrato de forma a não causar efeitos negativos no contexto social e garantir a sua aplicabilidade a todo e qualquer tipo de contrato. (SILVA)

Ocorre, entretanto, conforme aporta Tereza Ancona Lopez, que

A autonomia privada continua sendo o mais importante princípio do direito contratual, pois sem ele não há a criação dos negócios e o desenvolvimento da economia. $\mathrm{O}$ contrato é fonte do direito. A Constituição Federal coloca a livre iniciativa como fundamento da República e Ihe dá valor social. Porém coloca no seu exercício (da autonomia privada) não na sua existência, limites tendo em vista 0 respeito ao coletivo e a preservação do bem comum. (LOPEZ, 2010, p. 68)

Para Antônio Junqueira de Azevedo, o negócio jurídico deve ser sucessivamente verificado e analisado nos planos da existência, da validade e da eficácia. (AZEVEDO, 2002, p. 35)

Quanto ao plano da existência, deve-se observar a presença, na consecução do negócio jurídico, dos sujeitos, da vontade, do objeto e da forma, esta decorrente dos demais elementos constitutivos do fato jurídico.

No que se refere ao plano de validade do negócio jurídico, é necessário observar a capacidade do sujeito, a vontade declarada de forma livre e consciente e a licitude do objeto, que refere-se à sua possibilidade física ou jurídica.

Já o plano da eficácia trata das consequências jurídicas ou dos efeitos naturais do negócio realizado, de modo que, não havendo interferência voluntária das partes na produção dos efeitos do negócio jurídico, ocorrerá eficácia natural, decorrente da própria lei; e, na hipótese de interferência das partes na produção dos efeitos, configurar-se-á a condição, o termo ou o encargo, conforme o caso concreto. 
A função social do contrato, no escorço de Paulo Nalin (2001, p.226), divide-se em intrínseca - relativa à observância dos princípios da igualdade material, equidade e boa-fé objetiva pelos contratantes, decorrentes da cláusula constitucional da solidariedade; e extrínseca - destinada a observar as consequências do contrato nas relações sociais, considerando os seus reflexos a outros titulares que não somente os contratantes.

Nesse contexto, Jorge Cesar Ferreira da Silva(2002, p. 112) leciona que 0 art. 421 do Código Civil se preocupa com a operatividade da função social no plano da eficácia. Corroborando este entendimento, Zeno Veloso apregoa que

[...] a eficácia jurídica é a conseqüência principal do negócio. Em regra, ninguém declara a sua vontade para que não tenha sentido algum nem que gere qualquer efeito. Há casos, todavia, em que, considerando as circunstâncias, a lei recusa efeitos ao negócio. Nestes casos, a ineficácia não atinge os atos em si, pois eles são válidos, mas impede que os seus efeitos se projetem a determinadas pessoas. (VELOZO, 2003, p. 598)

Para J orge Cesar Ferreira da Silva (2003, p. 598), o art. 2.035 do Código Civil inclui a função social também no plano da validade, porque nenhuma convenção prevalecerá se contrariar preceitos de ordem pública, tais como os constantes no referido diploma legal, com a finalidade de assegurar a função social da propriedade e dos contratos.

Segundo o autor, tendo o Código Civil elevado o princípio da função social como integrante da ordem pública, houve simultaneamente a atribuição do papel da validade como reflexo da ordem pública nas relações contratuais de direito interno, ou seja, na inobservância da função social, invalida-se o contrato.

A propósito disto, Paulo Nalin assevera:

0 contrato que não cumpre a sua função social, em um primeiro momento, como negócio jurídico já foi reconhecido por meio da valoração social, gera efeitos jurídicos (atributivos, circulatórios e existenciais), de modo a ter suplantado o extrato da inexistência. Todavia, os efeitos que proporciona acabam sendo nocivos aos operadores contratuais, ou, ao menos, a uma das partes contratantes ou, ainda, à coletividade, esquadrinhando-se no campo da invalidade jurídica (nulidade ou anulabilidade). (NALIN, 2001, p. 236)

Para o autor, ainda que um contrato seja celebrado em desacordo à sua função social, poderá figurar no plano da existência, embora inválido, e por consequência, nulo. 
Por outro lado, segundo Jorge Cesar Ferreira da Silva(2002, p. 113), na hipótese de desrespeito à função social, o plano da eficácia será o mais afetado, isto porque a ordem pública é dotada de conteúdo axiológico. Desta forma, nem toda violação ao princípio da função social prejudicará a ordem pública. Isto porque, em face de seu conteúdo valorativo, o princípio da função social do contrato pode ser efetivado em diversos níveis, de maneira que, em um caso concreto, pode ocorrer violação da função social e não haver afronta à ordem pública, resultando apenas a ineficácia do contrato ou da cláusula discutida.

Neste passo, destaca-se a chamada nulidade virtual. Na medida em que 0 art. 421 do Código Civil é norma jurídica cogente, que não define uma sanção específica para sua transgressão, uma das sanções possíveis seria a nulidade, nos termos do art. 166, inc. VII, do Código Civil.

Oportuno lembrar, entretanto, o Enunciado 22, extraído da I Jornada de Direito Civil, promovida pelo Centro de Estudos Judiciários do Conselho da Justiça Federal, no período de 11 a 13 de setembro de 2002, que preceitua: "A função social do contrato, prevista no artigo 421 do novo Código Civil, constitui cláusula geral que reforça o princípio de conservação do contrato, assegurando trocas úteis e justas".

$\mathrm{Na}$ defesa da conservação fática e jurídica dos contratos, Antonio Junqueira de Azevedo leciona:

\begin{abstract}
0 princípio da conservação consiste, pois, em se procurar salvar tudo que é possível num negócio jurídico concreto, tanto no plano da existência, quanto da validade, quanto da eficácia. Seu fundamento prende-se à própria razão de ser do negócio jurídico; sendo este uma espécie de fato jurídico, de tipo peculiar, isto é, uma declaração de vontade (manifestação de vontade a que o ordenamento jurídico imputa os efeitos manifestados como queridos), é evidente que, para 0 sistema jurídico, a autonomia da vontade, produzindo efeitos, representa algo de juridicamente útil. (AZEVEDO, 2002, p. 66-67)
\end{abstract}

Para a conservação dos contratos, na hipótese de controvérsia judicial, o magistrado tem a prerrogativa de manter o negócio jurídico "atuante e gerador de efeitos" (DA SILVA, 2002, p. 117), optando, "entre a interpretação que leve à nulidade total do contrato e a interpretação que possibilite a manutenção de cláusulas válidas, pela interpretação que menos trará impacto à sociedade, atendendo ao princípio da conservação dos contratos e à função so cial dos contratos"(M ULLER).

Vale lembrar, de acordo com Antonio Junqueira de Azevedo, que: 
A função social do contrato busca, com a sua existência, propiciar um equilíbrio nas relações contratuais, aproximando-as da finalidade do Direito, a justiça, por meio da concretização do princípio da dignidade humana. Os contratos tutelados pelo Direito serão aqueles que obedecem, cumprem a sua função social. (MULLER)

Desta forma, a eficácia jurídica (LEONARDO, 2005, p. 20) do contrato e do exercício de alguns poderes contratuais, não se restringe apenas à manifestação de vontade dos contratantes, devendo ser fundada em valores superiores, de maneira que a liberdade de contratar deve respeitar a função social do contrato, até porque, os fins econômicos e sociais do contrato são indicadores de sua existência, validade e eficácia.

\section{Considerações Finais}

O conceito de função social do contrato é amplo e indefinido. Vários autores apresentam algumas definições, na tentativa de conceituar o instituo. Entretanto, devido à sua natureza de cláusula geral, a definição da função social do contrato ficará a cargo do magistrado, o qual deve compreender e interpretar o art. 421 do Código Civil, e, por meio de uma análise sistemática, só então aplicar a norma ao caso concreto, tendo a prerrogativa de realizar a exegese na hipótese de demanda fundada em violação da função social do contrato.

Com a evolução histórica e as mudanças ocorridas no contexto social, o Estado passou a adotar uma postura intervencionista nas relações privadas. Além do intervencionismo estatal, a principiologia dos contratos, antes adstrita aos princípios da liberdade de contratar, da força obrigatória dos contratos e da relatividade dos seus efeitos, passou a coexistir com os novos princípios: da boa-fé objetiva, do equilíbrio contratual e da função social do contrato, que relativizaram os princípios anteriores.

No âmbito dos direitos da personalidade, denota-se que a função contratual colabora para o desenvolvimento do ser humano, porém, sob o aspecto funcional, a função social dos contratos não pode ser elencada como um direito da personalidade, mas, sendo 0 contrato um instrumento para auxiliar e promover a concretude dos direitos da personalidade.

O princípio da função social do contrato é uma norma geral de ordem pública, pela qual o contrato deve ser necessariamente visualizado e interpretado de acordo com 0 
contexto da sociedade, não admitindo convenção particular contrária à função social, de modo que, eventual cláusula nesse sentido, deve ser afastada pelo magistrado.

0 art. 421 do Código Civil preconiza a limitação da liberdade de contratar. Porém, refere-se, em verdade, à liberdade contratual. Isto porque, a oportunidade e a conveniência de contratar não sofre entraves, pois as partes possuem a prerrogativa de optar pela realização ou não do contrato.

A liberdade contratual sofre significativas restrições em virtude da ordem pública, que representa a projeção do interesse social nas relações interindividuais, por meio da observância dos bons costumes e da estrutura social, econômica e política da comunidade.

A função social não é a razão que motiva a realização de um contrato. A função social restringe a liberdade contratual, na medida em que o contrato deve ser realizado nos limites e em consonância com sua função social, e não em razão desta.

O fundamento da função social do contrato encontra-se na Constituição Federal, atrelado ao princípio da solidariedade e na afirmação do valor social da livre iniciativa. Fundamentada na Constituição, compete à legislação infraconstitucional consolidar a funcionalização do contrato, inibindo efeitos negativos no contexto social e garantindo a sua aplicabilidade a todo e qualquer tipo de contrato.

No plano da validade, nenhum contrato poderá prevalecer, se contrariar preceitos de ordem pública. Neste caso, o plano da eficácia será o mais afetado, porque a ordem pública é dotada de conteúdo valorativo, de modo que o princípio da função social do contrato pode ser efetivado em diversos níveis.

Quanto à nulidade virtual, sendo a função social do contrato uma norma jurídica cogente, que não define uma sanção específica para sua transgressão, uma das sanções possíveis seria a nulidade. Porém, a função social tem a prerrogativa de reforçar o princípio de conservação fática e jurídica dos contratos. Deste modo, deve 0 juiz interpretar 0 contrato de modo a possibilitar a manutenção de cláusulas válidas, pela interpretação que menos trará impacto à sociedade e viabilizará, desta forma, sua função social. 


\section{Referências}

ALVES, José Ricardo Teixeira. 0 princípio da confiança e restituição de remuneração paga indevidamente a servidor público. Jus Navigandi, Teresina, ano 13, n. 1910, 23 set. 2008. Disponível em: «ttp://jus.uol.com.br/revista/texto/11763 >. Acesso em: 29 abr. 2011.

AZEVEDO, Antonio Junqueira de. Negócio Jurídico: existência, validade e eficácia. São Paulo: Saraiva, 2002.

AZIFEDO, Antonio Junqueira de. Princípios do novo direito contratual e desregulamentação do mercado - direito de exclusividade nas relações contratuais de fornecimento - função social do contrato e responsabilidade aquiliana do terceiro que contribui para inadimplemento contratual. In: Revista dos Tribunais, São Paulo, n. 750, p. 113-120, abr. 1998.

BASSO, Maurício. A função social como elemento da teoria geral dos contratos. 2008. 60 f. M onografia (Bacharelado em Direito)- Universidade do Vale do Itajaí, Tijucas, 2008.

BITTAR, Carlos Alberto. Os direitos da personalidade. Rio de Janeiro: Forense Universitária, 2003.

BRASIL. Conselho da Justiça Federal. Enunciados Aprovados - I Jornada de Direito Civil. Disponível em: http://daleth.cjf.jus.br/revista/ enunciados/lJornada.pdf Acesso em: 26 abr. 2011.

BRASIL. Lei 10.406, de 10 de janeiro de 2002. Disponível em:

বhttp://www.planalto.gov.br/ccivil_03/Leis/2002/L10406.htm>Acesso em: 05 jan. 2011.

CAPELO DE SOUSA, Rabindranath Valentino Aleixo. 0 Direito Geral de Personalidade. Coimbra: Coimbra, 1995.

CIFUENTES, Santos. Derechos personalíssimos. Buenos Aires: Astrea, 1985.

DA SILVA, Jorge César Ferreira. A boa-fé e a violação positiva do contrato. São Paulo: Renovar, 2002.

FIUZA, César. Para uma releitura da principiologia contratual. Disponível em: বtttp://www.fmd.pucminas.br/Virtuajus/ano2_2/Para\%20uma\%20releitura\%20da\%20princi piologia\%20contratual.pdf>Acesso em: 21 mai. 2011.

GADAM ER, Hans-Georg, Verdade e M étodo: Traços fundamentais de uma hermenêutica filosófica. Vozes: Petrópolis, 1997.

GAGLIANO, Pablo Stolze; PAM PLONA FILHO, Rodolfo. Novo curso de direito civil: contratos: teoria geral. São Paulo: Saraiva, 2005. 
GAGLIANO, Pablo Stolze. O novo Código Civil e os contratos celebrados antes da sua vigência. Jus Navigandi, Teresina, ano 8, n. 64, 1 abr. 2003. Disponível em:

४http://jus.uol.com.br/revista/texto/4002>. Acesso em: 21 maio 2011.

GOM ES, Orlando. Contratos. Rio de Janeiro : Forense, 1992.

GONÇALVES, Carlos Roberto. Direito Civil Brasileiro. Vol. III. Contratos e Atos Unilaterais. São Paulo: Saraiva, 2010.

LEONARDO, Rodrigo Xavier. A função social dos contratos: ponderações após o primeiro biênio de vigência do Código Civil. In: CANEZIN, Claud. Arte jurídica. Curitiba: Juruá, 2005.

LOPES, Ana M aria D'Ávila. A hermenêutica jurídica de Gadamer. In: Revista de Informação Legislativa. Brasília a. 37 n. 145 jan./mar. 2000.

LOPEZ, Teresa Ancona. Princípios Contratuais. In: FERNANDES, Wanderley (coord). Contratos Empresariais - Fundamentos e princípios. Série GVLAW. São Paulo: Saraiva, 2010.

LOUREIRO, Viviany Almeida; COSTA, Paulo Sérgio Weyl Albuquerque. A verdade da arte na hermenêutica de Gadamer e sua aplicação à ciência do direito. In: Congresso Nacional do CONPEDI, 17, 2008, p. 5670-5686. Anais... Florianópolis: Fundação Boiteux, 2008.

M ARTELLI, Ana Laura Teixeira. A boa fé objetiva e os limites da rescisão unilateral dos contratos administrativos por razões de interesse público. Revista de Direito Público, Londrina, v. 1, n. 6, p. 20-34, jan/abr. 2011. Disponível em:

বttp://www.uel.br/revistas/uel/index.php/direitopub/article/view/8337/7201>Acesso em: 01 jun. 2011.

M ELLO, Renata Rapold. A função social dos contratos. Jus Podivm. Disponível em: 〈ttp://www.juspodivm.com.br/>Acesso em: 15 mar. 2011.

M OTTA, Ivan Dias da; CAVALLINI, Viviane Cristina Rodrigues. 0 conceito de personalidade no âmbito dos direitos da personalidade. Revista Jurídica Cesumar - Mestrado. Maringá, v. 9, n. 620, p. 619-633, jul./ dez. 2009.

MÜLLER, Luciano Scherer. Função Social dos Contratos. Disponível em: \http://www.advogadobr.com/comentarios-ao-CPC/060612luciano_scherer_muller.php> Acesso em 29 abr. 2011.

NALIN, Paulo. Do Contrato: conceito pós-moderno; em busca de sua formulação na perspectiva civil-consitucional. Vol. II. Curitiba: Juruá, 2001.

NERY JÚNIOR, Nelson. NERY, Rosa M aria de Andrade. Código Civil Anotado e Legislação Extravagante. São Paulo: Revista dos Tribunais, 2003. 
NOBRE JÚNIOR, Edílson Pereira. 0 princípio da boa-fé e o novo código civil. In: Revista Forense. Rio de Janeiro, v. 367. p. 76-94.

NUNES, Gustavo Henrique Schneider. 0 princípio da boa-fé objetiva. Disponível em: বhttp://www.flaviotartuce.adv.br/artigosc/Gustavo_Boafe.doc>. Acesso em 29 abr. 2011.

PIM ENTA, M elissa Cunha. A função social do contrato. Revista Eletrônica da Faculdade De Direito da PUC-SP. Disponível em: «ttp://revistas. pucsp.br/index.php/red>Acesso em: 29 abr. 2011.

PONTES DE M IRANDA, Francisco Cavalcante. Tratado de Direito Privado. v. XXXVIII, Borsói: São Paulo, 1959.

ROSENVALD, Nelson. Coleção Prof. Agostinho Alvim. Dignidade humana e boa-fé no Código Civil. São Paulo: Saraiva, 2007.

ROTTA, M ariza. FERM ENTÃO, Cleide Aparecida Gomes Rodrigues. O Pacta Sunt Servanda Cláusula Rebus Sic Stantibus e o Equilíbrio das Relações Contratuais na Atualidade. Revista Jurídica Cesumar - M estrado, v. 8, n. 1, p. 194-218, jan/jul 2008.

SANTOS, Antonio Jeová. A função social do contrato. São Paulo: M étodo, 2004.

SETTI, M aria Estela Leite Gomes. O princípio da função social do contrato: conteúdo, alcance e a análise econômica do direito. In: Encontro Nacional do CONPEDI, 19, 2010, p. 416-428. Fortaleza. Anais... Fortaleza: Fundação Boiteux, 2010.

SILVA, Ligia Neves. O princípio da função social do contrato. Conteúdo e alcance. Análise econômica. In: Âmbito Jurídico, Rio Grande, 87, 01/04/2011. Disponível em: বhttp://www.ambitojuridico.com.br/site/index.php?n_link=revista_artigos_leitura\&artigo_id=9128>Acesso em: 03 abr. 2011.

SPINELI, Ana Claudia Marassi. Dos Direitos da Personalidade e o Princípio da Dignidade da Pessoa Humana. Revista Jurídica Cesumar - Mestrado, M aringá, v. 8, n. 2, p. 369-382, jul/dez 2008.

TARTUCE, Flávio. Os direitos da personalidade no novo código civil. Disponível em $<w w w$. flaviotartuce.adv.br/secoes/artigos/Tartuce_personalidade.doc $>$ Acesso em: 04 fev. 2011.

THEODORO JÚNIOR, Humberto. O contrato e sua função social. Rio de Janeiro: Forense, 2004. 
VELOSO, Zeno. Nulidade do negócio jurídico. In: ALVIM, José M anoel de Arruda; CÉSAR, Joaquim Portes de Cerqueira; ROSAS, Roberto (coord.). Aspectos Controvertidos do Novo Código Civil: escritos em homenagem ao ministro J osé Carlos M oreira Alves. São Paulo: Revista dos Tribunais, 2003.

WALD, Arnoldo. Obrigações e contratos. São Paulo: Revista dos Tribunais, 1992.

Artigo recebido em: 02 de junho de 2011 Artigo aprovado em: 21 de agosto de 2011 